\title{
Transport properties of carbide superconductor $\mathrm{La}_{2} \mathrm{C}_{3}$
}

\author{
J. S. Kim ${ }^{*}$, and R. K. Kremer ${ }^{\mathrm{b}}$ \\ ${ }^{a}$ Department of Physics, Pohang University of Science and Technology, Pohang, Korea \\ ${ }^{\mathrm{b}}$ Max-Planck-Institut fuer Festkoerperforschung, Heisenbergstrasse 1, Stuttgart, Germany
}

(Received 28 February 2013; revised 12 March 2013; accepted 14 March 2013)

\begin{abstract}
We investigate the electrical and thermal transport properties of a sesquicarbide superconductor $\mathrm{La}_{2} \mathrm{C}_{3}$, including electrical resistivity, thermoelectric power, and thermal conductivity. The electrical resistivity exhibits a typical metallic character with a saturation behavior at high temperatures. The thermoelectric power shows a metallic behavior with pronounced phonon-drag effect, comparable with pure metals. The broad peak of the thermal conductivity is observed in the superconducting state, which is rapidly suppressed by magnetic fields. These observations suggest that the electron-phonon scattering is significant in $\mathrm{La}_{2} \mathrm{C}_{3}$, which is relevant with the relatively high- $T_{\mathrm{c}}$ in $\mathrm{La}_{2} \mathrm{C}_{3}$ through strong electron-phonon coupling with low frequency phonon modes.
\end{abstract}

Keywords : carbide superconductor, transport property, electron-phonon coupling

\section{1. 서 론}

희토류 탄화물 $R_{2} \mathrm{C}_{3}$ ( $R=$ 희토류)는 체심 입방구조를 가지는 $\mathrm{Pu}_{2} \mathrm{C}_{3}$ 구조의 초전도체이다. 이 화합물에서는 강한 전자상호작용이 있을 것으로 생각되지 않음에도 불구하고 상대적으로 높은 온도에서 초전도 상전이가 관측되었다 [1-5]. 예를 들어 고온고압장비로 합성된 $\mathrm{Y}_{2} \mathrm{C}_{3}$ 의 경우는 Th도핑을 통해 초전도 상전이 온도 $T_{\mathrm{c}}$ 가 $17 \mathrm{~K}$ 까지 올라가는 것이 관측되었다가[1] 이후 Th 도핑 없이도 18 $\mathrm{K}$ 의 초전도 상전이가 발견되었다[2,3]. $\mathrm{La}_{2} \mathrm{C}_{3}$ 의 경우도 $13.5 \mathrm{~K}$ 의 초전도 상전이가 보고되었다 $[4,5]$. 이처럼 희토류 탄화물에서 나타나는 상대적으로 높은 상전이 온도는 A15 화합물에 버금가는 수준이다. 따라서 희토류 탄화물에서의 초전도 현상이 $\mathrm{MgB}_{2}$ [6]나 흑연 층간 화합물 [7-9], 압력 하에서의 리튬 금속 [10-12] 의 경우와 같이, 특이한 전자-포논 상호작용에 의한 것인지 밝히는 것은 희토류 탄화물의 초전도성에 대해서 이해하는 데 중요할 뿐만 아니라 앞으로 전자-포논 상호작용을 이용하여 더 높은 $T_{c}$ 의 초전도체를 구현하기 위해 중요하다고 할 수 있다.

전자-포논 상호작용을 통해 상대적으로 높은 초전도 상전이를 구현되는 경우는 낮은 진동수의 포논 모드가 중요한 경우와 높은 진동수의 포논 모드가 중요한 경우로 나눌 수 있다. 먼저 낮은 진동수의 포논 모드가 중요한 역할을 하는 경우, 높은 상전이 온도를 가지기 위해서는 상대적으로 강한 전자-포논 상호작용이 필요하다. 이는 잘 알려진 A15 화합물 초전도의 경우에 해당한다. 반면, 가벼운 원소로 이루어진 화합물의 경우, 높은 진동수의 포논 모드와 전자-포논 상호작용을 하게 되면 전체적으로 높지 않은 전자-포논 상호작용을 통해서도, 상대적으로 높은 온도에서 초전도 상전이를 가지게 된다. 이는 소위 말해 “금속 수소의 고온초전도 가능성” 로 불리는 시나리오 로서 [13] $\mathrm{MgB}_{2}$ [6] 나 압력하에서의 리틈 금속 [10-12]이

\footnotetext{
* Corresponding aurhor: js.kim@postech.ac.kr
}

이에 해당된다. 따라서 희토류 탄화물의 초전도성을 이해하기 위해서는 이 초전도체가 강한 전자-포논 상호작용 영역에 속하는지 그렇지 않은지, 그리고 어떤 종류의 전자-포논 상호작용을 하는지를 밝히는 것이 중요하다.

본 논문에서는 희토류 탄화물 초전도체 중 $\mathrm{La}_{2} \mathrm{C}_{3}$ 화합물 초전도성을 연구하기 위해 고품질의 $\mathrm{La}_{2} \mathrm{C}_{3}$ 시료를 합성하고 이에 대한 수송특성, 즉, 전기전도도, 열기전력, 열전도도를 측정한 결과를 보고한다. 이번 연구를 통해 초전도 상전이 이상 온도의 정상 상태에서 열기전력의 온도 의존성에 강한 포논-끌림 (phonon drag) 현상이 나타나는 것을 발견하였다. 또한 초전도 상전이 이하에서 열전도도의 온도 의존성이 봉우리 모양의 경향성을 가지는 것을 관측하였다. 이 두 가지 결과 모두 $\mathrm{La}_{2} \mathrm{C}_{3}$ 화합물에 강한 전자-포논 산란이 존재함을 나타낸다. 따라서 $\mathrm{La}_{2} \mathrm{C}_{3}$ 화합물의 초전도성은 강한 전자-포논 상호작용에 기인한 것으로 생각할 수 있고 이는 최근의 비열 연구결과와 일치한다 [14]. 이러한 결과로 볼 때, $\mathrm{La}_{2} \mathrm{C}_{3}$ 은 원래의 예상과 달리 탄소-탄소 결합에서 나타나는 높은 진동수의 포논보다는 주로 $\mathrm{La}$ 이 관여하는 낮은 진동수의 포논이 중요한 역할을 한다고 생각할 수 있다.

\section{2. 실험 방법}

다결정 $\mathrm{La}_{2} \mathrm{C}_{3}$ 시료는 수냉식 구리도가니에 담긴 란타늄 금속조각(Ames Laboratory, 99.99\%) 과 흑연 조각 (Deutsche Carbone, 99.99\%)을 순수 아르곤 가스 분위기하에서 아크 용융 법으로 녹여 합성하였다. 합성에 사용되는 흑연은 내부에 있을 수도 있는 수분을 제거하기 위해 합성 전에 섭씨 950 도의 고진공 $\left(P<10^{-5} \mathrm{mbar}\right)$ 에서 12 시간 이상 열처리를 하였다. 아크 용융은 최소한 6 번 이상 진행하였고 각각의 아크 방전 후 시료를 뒤집어 화학적인 균일성을 높였다. 합성된 후 시료는 공기중의 수분에 매우 민감하므로 이후 모든 작업은 수분이 0.1 
$\mathrm{ppm}$ 이하인 아르곤 가스분위기에서 진행되었다. 바로 반응한 $\mathrm{La}_{2} \mathrm{C}_{3}$ 화합물은 탄소 균일성 문제로 인해 $T_{\mathrm{c}}<6$ $\mathrm{K}$ 과 $T_{\mathrm{c}}=13.4 \mathrm{~K}$ 에서 두 번에 걸쳐 초전도 상전이를 보였다. 그러나 이러한 문제는 합성 중 탄소의 손실을 감안하여, 합성 시 탄소의 양을 최대 $10 \%$ 까지 추가하여 해결 하였다. 또한 합성 후 아르곤 가스가 차있는 탄탈륨 $(\mathrm{Ta})$ 관에서 섭씨 1000도로 5-7일 정도 열처리를 진행 하였고, 열처리 후 시간당 5 도로 상온까지 천천히 식혔다. 이러한 과정을 통해 $13.4 \mathrm{~K}$ 에서 단일 초전도 상전이를 가지는 고품질의 $\mathrm{La}_{2} \mathrm{C}_{3}$ 화합물을 얻었다 [5,14].

합성된 시료의 수송특성 연구를 위해 Quantum Design사의 물성 측정 장비 (PPMS)를 사용하였다. 열기전력과 열전도도 측정을 위해 다결정 시료를 아르곤 분위기에서 절단하여 $1 \times 1 \times 3 \mathrm{~mm}^{3}$ 의 막대 모양으로 만들어 시편을 준비하였다. 두 개의 온도 센서(Cernox)를 시료 중간에 붙여 온도 차를 측정하고, 한쪽 끝은 열원을 부착하고 다른 쪽 끝은 저온 홀더에 부착하는 4 단자 측정법을 사용하였다. 시료 한쪽의 온도를 국소적으로 증가시키기 위해 온도에 따른 저항 값이 미리 측정된 저항히터를 붙이고 전류 량을 인가하였다. 인가되는 열량은 미리 측정된 저항 값과 전류 량을 줄 (Joule)공식에 적용하여 얻었고 모든 측정은 $10^{-5} \mathrm{mbar}$ 이하의 고진공에서 이루어졌다.

\section{3. 결과 및 토의}

Figure 1에서 보는 것처럼 희토류 탄화물은 체심 입방형의 $\mathrm{Pu}_{2} \mathrm{C}_{3}$ 구조(I43d)를 가진다. 이 경우 아령모양으로 결합된 탄소 두 개가 희토류 금속으로 이루어진 변형된 12 면체 새장모양의 구조물 안에 갇혀 있는 특이한 결정구조를 보인다. 아령모양을 하고 있는 두 개의 탄소원자는 원자량이 작고 탄소 원자간의 간격이 매우 작기 때문에 높은 진동수를 가지는 탄소 포논 모드가 형성되게 된다. 실제로 $\mathrm{Y}_{2} \mathrm{C}_{3}$ 화합물에서 탄소-탄소 사이의 간격이 늘었다 줄었다 하는 포논 모드의 경우 $1440 \mathrm{~cm}^{-1}$ 의 높은 진동수를 가진다는 것이 제일원리 계산을 통해 얻어졌다[15]. 따라서 $\mathrm{La}_{2} \mathrm{C}_{3}$ 에서도 비슷한 크기의 진동수를 가지는 탄소-탄소 포논 모드가 있을 것으로 기대된다.

$\mathrm{La}_{2} \mathrm{C}_{3}$ 의 경우 탄소와 탄소간의 거리는 약 1.296(9) $\AA$ [14]으로 보통의 탄소 이중결합에 비해 약간 작다. 이는 탄소-탄소 공유결합 상태 중 반대결합 (antibonding) 전자 상태에서 $\mathrm{La}$ 의 $d$ 전자 상태로 전하 이동이 일어나기 때문이 (a)

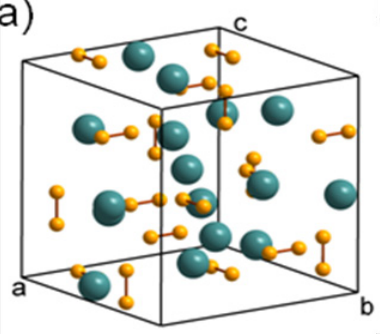

(b)

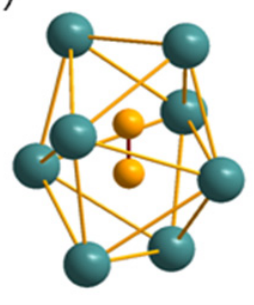

Fig. 1. (a) The crystal structure of $\mathrm{La}_{2} \mathrm{C}_{3}$. which crystallizes in the cubic $\mathrm{Pu}_{2} \mathrm{C}_{3}$ structure (I43d) with 8 f.u. in the unit cell. Large(small) spheres denote La (C). (b) The section with a $\mathrm{C}-\mathrm{C}$ dumbbell surrounded by a La metal atom bisphenoid in $\mathrm{La}_{2} \mathrm{C}_{3}$.

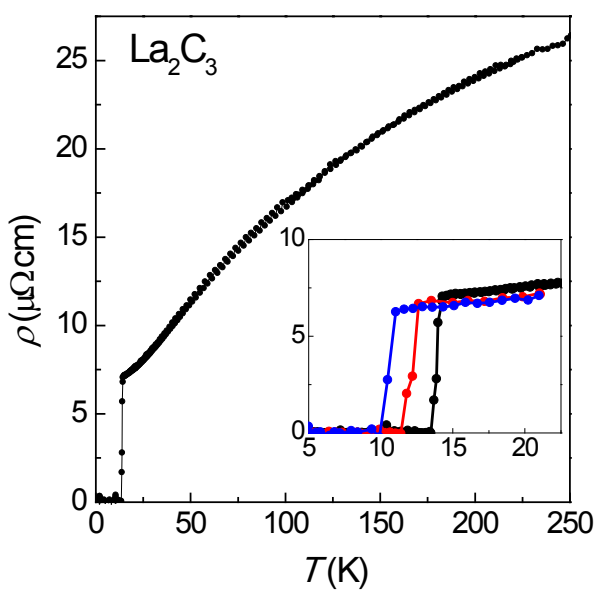

Fig. 2. Temperature dependence of the resistivity for $\mathrm{La}_{2} \mathrm{C}_{3}$. The inset shows the magnified view of the superconducting transition near $T_{\mathrm{c}}=13.5 \mathrm{~K}$ at various magnetic fields.

다. 따라서 탄소 전자 상태와 $\mathrm{La}$ 전자 상태가 어느 정도 결합되어 있을 수 있음을 알 수 있다. 탄소와 $\mathrm{La}$ 의 전자 상태와의 결합 정도는 두 원소 사이의 거리에 민감하므로 [5,14] 탄소의 포논 모드와 전자상태와의 강한 전자-포논 상호작용을 예상할 수 있다. 만약에 이 높은 탄소 포논 모드가 강하게 전자-포논 상호작용을 하게 되면 전체적으로는 낮은 전자-포논 상호작용의 크기를 가지더라도 높은 초전도 상전이를 가질 수 있게 된다. 반면, 무거운 희토류 금속의 포논 모드가 초전도에 중요한 경우에는 전체적으로 높은 전자-포논 상호작용이 있어야 실험적으로 관측된 상전이 온도를 설명할 수 있다. 그러므로 전자- 포논 상호작용의 크기에 대해서 알 수 있으면 초전도 에 중요한 포논 모드에 대한 단서도 얻을 수 있을 것으로 기대된다.

Figure 2는 합성된 $\mathrm{La}_{2} \mathrm{C}_{3}$ 의 온도에 따른 저항곡선을 나타낸다. 초전도 상전이를 나타내는 저항 감소는 $T_{\mathrm{c}}=$ $13.5 \mathrm{~K}$ 에서 매우 급하게 나타나는 것을 알 수 있다. 초전도 상전이 간격은 약 $0.3 \mathrm{~K}$ 으로 매우 작다. 특히 탄소의 결함이 있을 경우 시료의 불균일성 문제 때문에 높은 온도 $\left(T_{\mathrm{c}}=13.5 \mathrm{~K}\right)$ 와 낮은 온도 $\left(T_{\mathrm{c}} \sim 6 \mathrm{~K}\right)$ 에서 초전도 상전이가 동시에 관측되는 것이 알려져 있는데 [5] 본 논문에서 합성된 시료에서는 단일 상전이가 관측되었음을 알 수 있다[3]. 이는 합성된 시료의 품질이 매우 좋다는 것을 의미한다. 자기장을 걸어주었을 때 초전도 상전이는 낮은 온도로 이동하였다. 임계자기장의 온도의 대한 변화는 약 $d H_{c 2} / d T=0.5 \mathrm{~T} / \mathrm{K}$ 으로 이는 기존 결과와 잘 일치한다 [14].

초전도 상전이 위의 정상상태에서는 저항의 온도 의존성은 아래로 굽은 형태를 보이는데 이는 고온에서 Ioffe-Regal 극한 근처에서 나타나는 일반적인 현상이다 [16,17]. 이러한 현상은 고온에서 전자와 포논 간의 산란이 심해지면서 저항이 점차 증가하고 이에 따라 전하의 평균자유거리 (mean free path)가 점점 작아지다가 격자 상수와 비슷해지면서 더 이상 저항이 증가하지 않게 되어 나타난다. 이러한 현상은 불순물이 많아 전기전도도가 나쁜 금속에서 나타나는 것이 보통이다. 그러나 $\mathrm{La}_{2} \mathrm{C}_{3}$ 의 경우는 저온에서 불순물에 의한 저항 값이 대략 $\sim 7 \mu \Omega \mathrm{cm}$ 로 상대적으로 낮다. 그러므로 이 경우는 온도에 따른 저항 변화가 심하기 때문에 Ioffe-Regal 극한에 쉽게 도달한 것으로 여겨진다. 이러한 온도경향은 초전도 상전이 위 
정상상태에서 전하와 포논 간의 산란이 온도 증가에 의해 급격하게 늘어나는 것을 의미한다. 따라서 전자-포논 산란효과가 보통의 금속에 비해 강하다는 것을 알 수 있다. 전자-포논 상호작용이 높은 A 15 화합물의 경우도 비슷한 저항의 온도의존성이 보고된 바 있다 [18-20].

강한 전자-포논 산란은 열기전력에서도 확인할 수 있다. Figure 3 은 온도에 따른 열기전력을 표시한 것이다. 열기전력이 음의 부호를 가지는 것은 전하수송을 담당하는 대부분의 전하가 전자라는 것을 의미한다. 초전도 상전이 온도에서 열기전력도 0 으로 급격히 감소하였다. 초전도 상태에서는 엔트로피의 흐름이 존재하지 않고 따라서 엔트로피 흐름에 비례하는 열기전력 역시 0 이 된다. 자기장 하에서 초전도 상전이가 낮은 온도 구간으로 이동하는 것은 열기전력 결과에서도 확인 할 수 있었다.

상전이 온도 이상의 정상상태에서의 열기전력은 금속의 열기전력의 온도의존성으로 이해할 수 있는 데 이 때 온도 의존성은 보통 두 가지 다른 종류의 전하수송효과에 의해 기인한다. 하나는 금속성의 전하에 의해 나타나는 온도에 선형적으로 비례하는 전하확산 항이다. 이는 에너지에 무관한 산란시간을 가정할 때 아래와 같은 전하 확산모델 식을 만족하는 것이 알려져 있다 [21].

$S=\left(\pi^{2} k_{B}^{2} / 2 e E_{F}\right) T$.

여기서 $S$ 는 열기전력이고, $k_{B}$ 는 볼츠만 상수이고, $E_{F}$ 는 페르미 준위이다. 이에 더해 저온에서 봉우리모양으로 나타나는 것은 포논 끌림 (phonon drag) 현상에 의한 기여 때문이다. 포논 끌림 현상은 금속 양단에 온도 차가 있어 열전도가 진행될 경우 포논의 흐름이 생기게 되는데 이때 포논과 전자 사이의 산란을 통해 포논의 흐름이 전하의 흐름을 유도하기 때문에 일어난다. 이처럼 포논에 의해 끌린 전하의 흐름은 시편의 양단 간의 전하 분포에 불균형을 야기하게 되므로 결과적으로 열기전력에 기여를 하게 된다.

보다 정량적인 분석을 위해 정상상태에서 관측된 열기전력 곡선을 아래의 식으로 분석하였다 [22].

$S=A T+\frac{T^{3}}{B+C T^{4}}$.

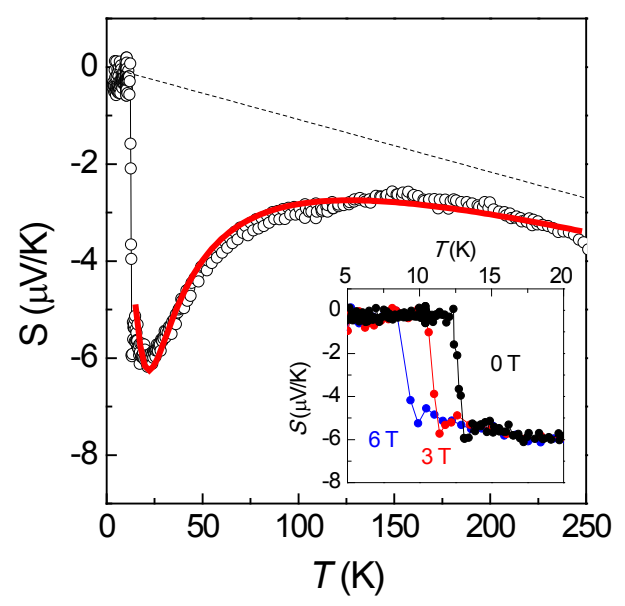

Fig. 3. Thermoelectric power $S(T)$ of $\mathrm{La}_{2} \mathrm{C}_{3}$ as a function of temperature. The red solid line is the fit to the equation (2) and the dashed line is the contribution from the diffusion model. The inset shows the superconducting transition in $S(T)$ near $T_{\mathrm{c}}$ under various magnetic fields.
여기서 첫 번째 항은 온도에 선형적으로 변하는 전하 확산 모델 식에 해당한다. 두 번째 항은 포논 끌림 현상을 기술하는 경험적인 식이다. 포논 끌림 현상에 의한 열기전력은 저온에서는 $T^{3}$ 에 비례하고 고온에서는 $1 / T$ 의 경향성을 띤다. 이때 온도가 0 으로 가는 극한에서 $T^{3}$ 항에 계수인 $B$ 는 데바이 (Debye) 온도의 3 제곱에 비례하게 된다. Figure 3에서 빨간 실선으로 표시한 것은 실험치를 식 (2)의 모델에 맞춘 결과이다. 전체적인 경향성이 잘 맞는 것을 알 수 있고 이때 얻은 각 계수는 $\mathrm{A}=0.0108$ (1) $\mu \mathrm{V} / \mathrm{K}^{2}, \mathrm{~B}=-427(7) \mathrm{K}^{4} / \mu \mathrm{V}, \mathrm{C}=-0.0057$ (3) $\mu \mathrm{V}^{-1}$ 이다. 전하 확산 모델식에 의한 항은 점선으로 표시한 것과 같고, 측정치에서 이를 뺀 것이 포논 끌림 현상에 의한 항이다. Figure 3 에서 보는 것과 같이, 저온에서 포논 끌림 효과에 의한 열기전력이 전하확산에 의한 열기전력에 비해 훨씬 크다는 것을 알 수 있다. 예를 들어 약 $25 \mathrm{~K}$ 의 경우 대략 30 배 이상 크게 나타난다.

포논 끌림 현상은 보통 불순물이나 경계에 의한 전하산란이 적은 깨끗한 금속에서 주로 관측된다. 불순물 산란이 심한 경우에는 포논에 의해 끌려진 전하의 흐름이 불순물에 의해 방해 받게 되므로 열기전력에 대한 기여가 현저하게 감소하게 된다. $\mathrm{La}_{2} \mathrm{C}_{3}$ 의 경우 상대적으로 강한 포논 끌림 현상이 보이는 데 이는 깨끗한 금속시료인 $\mathrm{Pt}$ 에서 관측되는 것과 그 크기가 비슷하거나 $\mathrm{Cu}$ 등에서 관측되는 것보다는 오히려 더 크다 [21]. 이러한 결과는 현재 측정에 사용한 $\mathrm{La}_{2} \mathrm{C}_{3}$ 의 시편이 다결정임을 고려할 때 상당히 특이하다고 할 수 있다. 다시 말해, 단결정 시료에 비해 다결정 시료에서 불순물 산란이나 경계 산란이 심할 것이므로 포논 끌림 현상 역시 심하지 않을 것으로 예상할 수 있으나 실제로는 상당히 큰 포논 끌림 현상이 관측되었다. 이러한 결과는 $\mathrm{La}_{2} \mathrm{C}_{3}$ 의 전하와 포논 간의 산란이 다른 물질에 비해 매우 크다는 간접적인 증거로 생각될 수 있다. 특히 열기전력의 포논 끌림 현상이 높은 진동수의 포논 모드에 의해서는 일어나지 않는 점을 감안하면, $\mathrm{La}_{2} \mathrm{C}_{3}$ 의 열기전력에서 관측된 강한 포논 끌림 현상은 낮은 진동수의 포논 모드와 전하간의 상호작용이 크다는 것을 의미한다고 할 수 있다.

Figure 4 는 $\mathrm{La}_{2} \mathrm{C}_{3}$ 의 열전도도를 측정한 결과이다. 먼저 초전도 상전이 위의 온도인 정상상태에서의 전체적인 온도의존성은 보통의 금속과 유사한 것을 알 수 있다 [23]. 다만, 금속의 경우 저온에서 열전도도가 심하게 증가했다가 감소하여 봉우리 모양을 나타내는 것이 나타나는데 $\mathrm{La}_{2} \mathrm{C}_{3}$ 이 경우는 이러한 경향이 보이지 않았다. 이는 다결정 시료내부의 불순물에 의해 산란이 심하기 때문으로 보인다. 보통 금속에서 열전도는 전하에 의한 열전도 $\kappa_{e}$ 와 포논에 의한 열전도 $\kappa_{p}$ 의 합으로 생각할 수 있다. 이때 $\kappa_{e}$ 는 비더만-프란츠법칙 (Wiedemann-Franz law) $\kappa_{e} \rho / \mathrm{T}=$ $L_{O}$ 로 구할 수 있고, 여기서 $L_{0}$ 는 로렌츠 상수 $L_{0}=$ $2.45 \times 10^{-8} \mathrm{~W} \Omega / \mathrm{K}^{2}$ ) 이고 $\rho$ 는 비저항이다. 이를 통해 얻은 $\kappa_{e}$ 는 Fig. 4 에서 점선으로 표시되어있다. 그림에서 보는 바와 같이 전하에 의한 열전도 기여 $\kappa_{e}$ 는 포논에 의한 기여 $\kappa_{p}$ 에 비해 3-4배 정도 작다는 것을 알 수 있다.

고온 쪽에서는 열전도도가 대략 $T^{2}$ 을 따라 증가하는데 이는 포논이 전도될 때 전하에 의해 산란을 받기 때문이다. $\mathrm{La}_{2} \mathrm{C}_{3}$ 의 경우도 비슷한 온도경향성이 관측되었다. 저온에서는 보통 $\kappa_{p}$ 가 $T^{3}$ 경향성을 따르는데 이는 열전도도가 포논의 비열의 온도의존성을 그대로 따르기 때문이다. 그러나 Fig. 4 에서는 $\mathrm{La}_{2} \mathrm{C}_{3}$ 의 경우 초전도 상전이 위에서 언덕모양의 온도의존성을 가지는 것을 알 수 있다. 이러한 현상은 낮은 진동수를 가지는 포논 모드가 


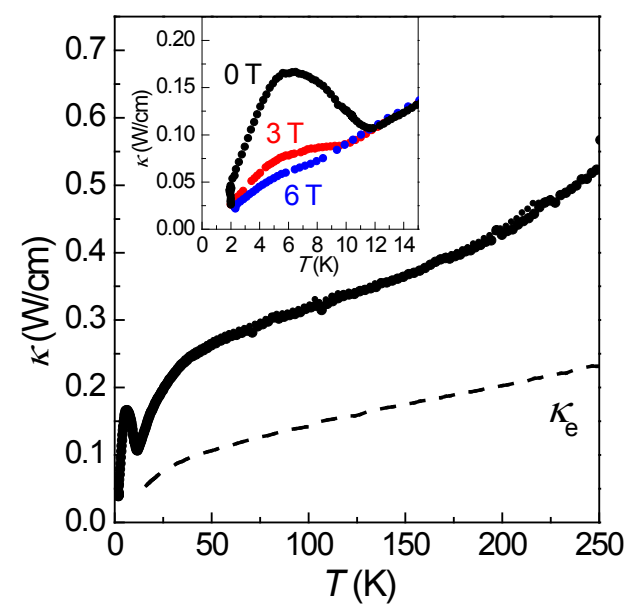

Fig. 4. Thermal conductivity $\kappa(T)$ of $\mathrm{La}_{2} \mathrm{C}_{3}$ as a function of temperature. The dashed line is the contribution from the electrons $\kappa_{\mathrm{e}}(T)$ estimated from Wiedemann-Franz law. The inset shows the $\kappa(T)$ below the superconducting transition temperaturer $T_{\mathrm{c}}$ under various magnetic fields.

중요한 경우에 나타나는데 예를 들어 낮은 진동수의 포논 모드에 의해 초전도가 발현되는 것으로 알려진 $\mathrm{CaAlSi}$ 에서 관측되었다 [24]. 그러므로 이러한 결과는, 앞서 논의한 것과 마찬가지로, $\mathrm{La}_{2} \mathrm{C}_{3}$ 에서도 낮은 진동수의 포논 모드가 중요할 수 있다는 점을 시사한다고 하겠다.

초전도 상태에서는 열전도도가 갑자기 증가하는 것이 관측되었다. 초전도 상태에서는 전하에 의한 엔트로피의 흐름이 존재할 수 없으므로 초전도 상전이 온도 아래로 내려가면서 열전도도가 낮아지는 것이 보통이다. 그러나 $\mathrm{La}_{2} \mathrm{C}_{3}$ 의 경우 상전이 온도 아래에서 열전도도가 갑자기 증가하였다가 다시 감소하는 현상이 관측되었다. 이러한 경향은 포논에 의한 열전도에서 포논과 전하의 산란이 중요한 역할을 하는 경우 나타나는 것으로 알려져 있다 [23] 초전도 상전이가 일어나면, 보통의 전하들이 초전도 쿠퍼쌍으로 변환되면서 더 이상 전자-포논 산란에 기여하지 못하게 되고, 결과적으로는 Fig. 4 에서 보는 것과 같이, 초전도 상전이 온도 아래에서 열전도도가 갑자기 증가하게 된다. 이는 정상 상태에서 예측한 전하에 의한 열전도도 $\kappa_{e}$ 가 포논에 의한 열전도도 $\kappa_{p}$ 에 비해 더 낮은 것과 일치하는 결과이다. 자기장에 의해 열전도도의 봉우리가 급격히 감소하는 현상도 위의 설명과 잘 일치한다고 하겠다.

이처럼 열전도도의 초전도상태에서 봉우리 모양을 보이는 경향은 불순물이 많을 경우 관측이 되지 않는 것으로 알려졌다. 이는 포논 자유 이동 거리가 불순물에 의해 제한되기 때문인데, 다결정인 $\mathrm{La}_{2} \mathrm{C}_{3}$ 에서 이러한 현상이 잘 관측되는 것은 상당히 특이하다고 하겠다. 따라서 $\mathrm{La}_{2} \mathrm{C}_{3}$ 의 초전도 상태에서 이러한 열전도 특성을 관측한 것은 $\mathrm{La}_{2} \mathrm{C}_{3}$ 에서 전자- 포논 산란이 강하다는 것을 드러내는 결과라고 할 수 있다.

앞서 언급한 $\mathrm{La}_{2} \mathrm{C}_{3}$ 의 수송특성, 즉 전기전도도, 열기전력, 열전도도 모두 강한 전자-포논 상호작용을 나타낸다고 할 수 있다. 이는 희토류 탄화물 초전도체의 상대적으로 높은 초전도 상전이 온도가 높은 진동수의 탄소 포논 보다는 $\mathrm{La}$ 과 관련된 낮은 진동수의 포논과 상호작용을 심하게 한다는 것을 의미한다. 이러한 결과는 $\mathrm{La}_{2} \mathrm{C}_{3}$ 의 비열에 대한 연구 결과와도 일치한다 [14]. 비열 측정을 통해 얻은 초전도 특성으로 예측한 주된 포논 모드의 에너지 크기는
대략 $110 \mathrm{~K}$ 로 이는 데바이 (Debye) 온도의 약 $30 \%$ 밖에 되지 않는다. 그러므로 $\mathrm{La}_{2} \mathrm{C}_{3}$ 초전도체는 전자-포논 상호작용이 강한 초전도체로서, 초전도 발현에 주된 역할을 하는 포논 모드는 $\mathrm{La}$ 에 관련된 낮은 진동수의 포논 모드임을 알 수 있다.

\section{4. 결 론}

본 논문에서는 희토류 탄화물 초전도체인 $\mathrm{La}_{2} \mathrm{C}_{3}$ 화합물의 전기전도도, 열기전력, 열전도도를 측정하였다. 측정을 위해 고품질 $\mathrm{La}_{2} \mathrm{C}_{3}$ 화합물을 아크용융법을 이용해 합성하였다. 수송특성 중 특히 열기전력에서 강한 포논-끌림 (phonon drag) 현상을 정상 상태에서 관측하였다. 이는 낮은 진동수의 포논 모드와 전하간의 강한 산란의 실험적인 증거로 생각된다. 또한 열전도도에서 초전도 상전이 이하에서 봉우리 모양의 경향성을 가지는 것을 관측하였고, 이 역시 $\mathrm{La}_{2} \mathrm{C}_{3}$ 에 강한 전자-포논 산란이 존재함을 나타낸다고 할 수 있다. 따라서 $\mathrm{La}_{2} \mathrm{C}_{3}$ 화합물의 초전도성은 강한 전자-포논 상호작용에 기인한 것으로 생각할 수 있고 주된 포논 모드는 낮은 에너지의 희토류 원소 관련 포논 모드라는 것을 알 수 있다. 따라서 상대적으로 높은 초전도 상전이 온도를 가지는 희토류 탄화물 초전도체는 $\mathrm{MgB}_{2}$ 보다는 $\mathrm{A} 15$ 초전도체와 더 유사하다고 할 수 있다.

\section{ACKNOWLEDGMENT}

This work was supported by the National Research Foundation through Basic research program (Grants No. 2010-0005669, Grant No. 2012-013838).

\section{REFERENCES}

[1] M. C. Krupka, A. L. Giorgi, N. H. Krikorian, and E. G. Szklarz, "High-pressure synthesis of yttrium-thorium sesquicarbide: A new high-temperature superconductor", J. Less-Common Met. 19, 113 (1969).

[2] G. Amano, S. Akutagawa, T. Muranaka, Y. Zenitani, and J.Akimutsu, "Superconductivity at $18 \mathrm{~K}$ in Yttrium Sesquicarbide System, $\mathrm{Y}_{2} \mathrm{C}_{3}$ ", J. Phys. Soc. Jpn. 73, 530 (2004)

[3] T. Nakane, T. Mochiku, H. Kito, M. Nagao, J. Itoh, H Kumakura,and Y. Takano, "Superconducting properties of the $18 \mathrm{~K}$ phase in yttrium sesquicarbide system", Appl. Phys. Lett. 84, 2859 (2004).

[4] A. Simon and Th. Gulden, " $\mathrm{La}_{2} \mathrm{C}_{3}$ und seine Reaktion mit Wasserstoff", Z. Anorg. Allg. Chem. 630, 2191 (2004)

[5] J. S. Kim, R. K. Kremer, O. Jepsen, and A. Simon, "Electronic and superconducting properties of the binary carbide $\mathrm{La}_{2} \mathrm{C}_{3}$ ", Curr. Appl. Phys. 6, 897 (2006).

[6] J. Nagamatsu, N. Nakagawa, T. Muranaka, Y. Zenitani, and J. Akimitsu, "Superconductivity at $39 \mathrm{~K}$ in magnesium diboride", Nature (London) 410, 63 (2001)

[7] T. E. Weller, M. Ellerby, S. S. Saxena, R. P. Smith, and N. T. Skipper, "Superconductivity in the intercalated graphite compounds $\mathrm{C}_{6} \mathrm{Yb}$ and $\mathrm{C}_{6} \mathrm{Ca}$ ", Nat. Phys. 1, 39 (2005)

[8] N. Emery, C. Hérold, M. d'Astuto, V. Garcia, C. Bellin, J. F. Marêché, P. Lagrange, and G. Loupias, "Superconductivity of Bulk CaC6", Phys. Rev. Lett. 95, 087003 (2005).

[9] J. S. Kim, L. Boeri, J. R. O’Brien, F. S. Razavi, and R. K. Kremer, "Superconductivity in Heavy Alkaline-Earth Intercalated Graphites”, Phys. Rev. Lett. 99, 027001 (2007). 
[10] K. Shimizu, H. Kimura, D. Takao, and K. Amaya, "Superconductivity in compressed lithium at $20 \mathrm{~K}$ ", Nature (London) 419, 597 (2002)

[11] V. V. Struzhkin, M. I. Eremets, W. Gan,H.-K. Mao, and R. J. Hemley, "Superconductivity in Dense Lithium”, Science 298, 1213 (2002)

[12] S.Deemyad and J. S. Schilling, "Superconducting Phase Diagram of Li Metal in Nearly Hydrostatic Pressures up to 67 GPa", Phys. Rev. Lett. 91, 167001 (2003)

[13] N. W. Ashcroft, "Metallic Hydrogen: A High-Temperature Superconductor?", Phys. Rev. Lett. 21, 1748 (1968)

[14] J. S. Kim, Wenhui Xie, R. K. Kremer, V. Babizhetskyy, O. Jepsen, A. Simon, K. S. Ahn, B. Raquet, H. Rakoto, J.-M. Broto, and B. Ouladdiaf, "Strong electron-phonon coupling in the rare-earth carbide superconductor $\mathrm{La}_{2} \mathrm{C}_{3}$ ", Phys. Rev. B 76, 014516 (2007).

[15] D. J. Singh and I. I. Mazin," Electronic structure and electron-phonon coupling in the $18 \mathrm{~K}$ superconductor $\mathrm{Y}_{2} \mathrm{C}_{3}$ ”, Phys. Rev. B 70, 052504 (2004)

[16] A. F. Ioffe, and A. R. Regel, Prog. Semicond. 4, 237 (1960).

[17] O. Gunnarsson, M. Calandra, J. E. Han, "Colloquium: Saturation of electrical resistivity”, Rev. Mod. Phys. 75, 1085 (2003).
[18] Z. Fisk and G. W. Webb, "Saturation of the high-temperature normal-state electrical resistivity of superconductors", Phys. Rev. Lett. 36, 1084 (1976).

[19] H. Wiesmann, M. Gurvitch, H. Lutz, A. Ghosh, B. Schwartz, M. Strongin, P. B. Allen, and J.W. Halley, "Simple model for characterizing the electrical resistivity in A-15 superconductors", Phys. Rev. Lett. 38, 782 (1977).

[20] M. Gurvitch, A. K. Ghosh, B. L. Gyorffy, H. Lutz, O. F. Kammerer, J. S. Rosner, and M.Strongin, "Effects of disorder on the transition temperature and transport properties of a low-Tc A15 superconductor: $\mathrm{Mo}_{3} \mathrm{Ge} "$, Phys. Rev. Lett. 41, 1616 (1978)

[21] F. J. Blatt, P. A. Schroeder and C. L. Foiles Thermoelectric Power of Metals (New York: Plenum) (1976).

[22] M. Mudgel, V. P. S. Awana, R. Lal, H. Kishan, L. S. Sharth Chandra, V. Ganesan, A. V. Narlikar, and G. L. Bhalla "Anomalous thermoelectric power of the $\mathrm{Mg}_{1-\mathrm{x}} \mathrm{Al}_{\mathrm{x}} \mathrm{B}_{2}$ system with $\mathrm{x}$ =0.0-1.0", J. Phys.: Condens. Matter 20, 095205 (2008).

[23] R. Berman, Thermal conduction in Solids (Clarendon Press, Oxford) (1976).

[24] A.C. Abhyankar, C.P.Fang, C. S. Lue, Y. K. Kuo, "Thermal transport properties in the normal state of $\mathrm{CaAl}_{\mathrm{x}} \mathrm{Si}_{2-\mathrm{x}}$ superconductors", J. Phys. Chem. Solids 72, 589 (2011). 